\title{
The Effect of Different Applications on In vitro Bulb Development of an Endemic Hyacinth Plant (Hyacinthus orientalis L. subsp. chionophyllus Wendelbo) Grown in Turkey
}

\author{
Selay Doğan ${ }^{1, a, *}$, Gülat Çağlar ${ }^{2, b}$, Esra Bulunuz Palaz ${ }^{3, c}$ \\ ${ }^{1}$ Biological Diversity and Genetic Resources Department, Aegean Agricultural Research Institute, 35661 İzmir, Turkey \\ ${ }^{2}$ Department of Horticulture, Faculty of Agriculture, Kahramanmaraş Sütçü Imam University, 46050 Kahramanmaraş, Turkey \\ ${ }^{3}$ East Mediterranean Transitional Zone Agricultural Research Institute, 46050 Kahramanmaraş, Turkey \\ *Corresponding author
}

\section{A R T I C L E I N F O A B S T R A C T}

\section{Research Article}

Received : 31/03/2020

Accepted : 26/06/2020
In this study the effects of different sucrose concentrations, and the combinations of jasmonic acid (JA) with auxins (IAA or NAA) or with cytokinin (2iP) on the bulb induction and rooting of in vitro plantlets of Hyacinthus orientalis subsp. chionophyllus Wendelbo, which is endemic in Turkey, were investigated. The effect of four different sucrose concentrations $\left(30,45,60\right.$ and $\left.90 \mathrm{~g} \mathrm{~L}^{-1}\right)$ on bulb formation in tissue culture was investigated. These plantlets were cultured on MS medium supplemented with several concentrations and combinations of JA $\left(0.0,1.0,2.0 \mathrm{mg} \mathrm{L}^{-1}\right)$ and $2 \mathrm{iP}$ $\left(0.0,0.25\right.$ and $\left.0.50 \mathrm{mg} \mathrm{L}^{-1}\right)$, IAA or NAA $\left(0.5,1.0 \mathrm{mg} \mathrm{L}^{-1}\right)$. In JA- 2iP treatment, the highest number of bulblets (13.7 number/explant) was obtained by the combinations of JA $1.0 \mathrm{mg} \mathrm{L}^{-1}+2 \mathrm{PP} 0.25$ $\mathrm{mg} \mathrm{L}^{-1}$. Also, the largest bulblets with the mean diameter of $7.9 \mathrm{~mm}$ were found on MS medium supplemented with JA $2.0 \mathrm{mg} \mathrm{L}^{-1}$. In JA - Auxin treatment, the mean root number per bulblet was highest (17.9 number/explant) and root formation rate was maximum $(81.14 \%)$ on MS medium supplemented with IAA $1.0 \mathrm{mg} \mathrm{L}^{-1}+\mathrm{JA}_{2} .0 \mathrm{mg} \mathrm{L}^{-1}$.
Keywords:

Plant propagation

In vitro

Growth regulators

Ornamental plants

Bulb formation selay.eldogan@tarim.gov.tr bulunuzesra@hotmail.com
(iD) https://orcid.org/0000-0003-0589-3963 iD https://orcid.org/0000-0001-7795-496X gulatcaglar@gmail.com

https://orcid.org/0000-0001-8444-1230

\section{Introduction}

The hyacinth plant (Hyacinthus orientalis L.) which was once thought to belong to the Liliaceae family is now classified in the Hyacinthaceae family. The hyacinth is a perennial herbaceous plant with $15-20 \mathrm{~cm}$ in height. A group of 5-15 flowers which has a strong scent makes a sparse bunch on the plant stem. Naturally grown hyacinth plants can be found in the Southwest Asia, Northwest of Syrie and Lebanon. In Turkey, hyacinth plants are grown in the southern part of Anatolia and inner regions where Hyacinthus orientalis subsp. orientalis and Hyacinthus orientalis subsp. chionophyllus Wendelbo can be found in nature, but only the latter one is an endemic to Turkey. Leaf diameters and flower tube lengths are the main criteria to distinguish the difference between these two taxons (Yüzbaşığlu, 2003).

In Turkey, the B6, B7 and C6 sections, including the provinces of Kahramanmaraş, Sivas, Adana, Malatya, Tunceli, Erzincan and Kayseri, are the natural distribution areas of Hyacinthus orientalis subsp. chionophyllus Wendelbo. These hyacinth plants can be found mostly on the rocky slopes within these areas.

Like most geophyte plants, the hyacinth plant can be reproduced by the separation of its storage organs. However, the flowering of the multiplied plants is a long process which takes 4-5 years. In vitro culture of geophytes offers alternative methods instead of conventional methods, with many advantages such as increasing the multiplication coefficient, reducing the labour required, obtaining the virulent plant under controlled conditions in a short time.

There have been many studies on the growing techniques, propagation methods and chemical ingredients of the geophyte species which also might have economic importance as ornamentals. In these geophytes, in vitro studies are still being carried out with several objectives. These objectives include the use of plant growth regulators 
on plant development (Pierik et al., 1975; Rice et al., 1983; Squires et al., 1991; Bach, 1992; Podwyszynska, 2004; Mirici et al., 2005; Sun X et al., 2010), the treatments for breaking dormancy of tuberous plants (Li-Nagasuga et al., 2000; Jansky and Hamernik, 2015) and the use of different carbohydrate sources on tuber growth (Taeb et al., 1990, Sun et al., 2012). In Turkey, there are several works on the propagation and growing techniques for some of these endemic taxons such as Origanum sipyleum (Oluk and Çakır, 2009; Sevindik et al., 2018); Muscari azureum (Urnabey, 2010); Erodium somanum (Çetin et al., 2016); Silene bolanthoides (Çördük et al., 2018), Iris sari (Doğan and Çağlar, 2020).

Hyacinth, as an ornamental plant, has also been explored by many ethnobotanists for their use in alternative medical treatments. The endemic Hyacinthus orientalis subsp. chionophyllus has been reported to benefit from antihemorrhoidal diseases, prostate diseases, hemostatis and wound healing leaves and bulb preparations (Kahraman and Kocabas, 2001; Çömlekçioğlu and Kahraman, 2008; Tuzlacı and Doğan, 2010; Altundağ and Öztürk, 2011; Kayıran and Özkan, 2017).

In plants with underground storage organs, carbohydrates that accumulate as a result of photosynthesis are transported to storage organs, which helps to develop onion, bulb or rhizome-like structures. The growth of these developing storage organs is also crucial to the flowering capacity of plants (Khodorova and Boitel-Conti, 2013). However, varying concentrations of sucrose and precooling applications can be very useful in the development of a plant or microbulblets from bulb explants of hyacinthus, tulips, lilium and glodiole (Takayama and Misawa, 1980; Halmer and Bewley, 1982; Heidema et al., 1985; Lian et al., 2003; Kizil et al., 2016).

In addition to the plant growth regulators used in in vitro studies, JA and Jasmonetler are also known as endogenous growth regulators. Some studies showed that the roots were shaped by the effect of methyl jasmonate or JA, as in cut shoots or callus/meristem cultures (Zimmerman and Vick, 1983; Ravnikar et al., 1990; Podwyszynska et al., 2015). Noriji et al. (1992) found that the level of JA in bulbous onion plants was about 3 times higher than that of bulbless onions when they compared the level of JA in bulbous and bulbless onion plants. However, it was also reported that the $10^{-4}-10^{-6} \mathrm{M} \mathrm{JA}$ applications did not cause bulb formation in onion leaf scale, which was due to the significant association between endogenous JA and onion bulbs. On the other hand, some researchers reported that roots were formed in onion with $10^{-5} \mathrm{M} \mathrm{JA}$ (Koda, 1997); also the addition of JA to the media induced in vitro garlic bulb formation (Ravnikar et al., 1993). Santos and Salema (2000) reported in vitro culture of Narcissus triandrus L. shoots in medium containing JA enhanced bulb number and quality. Jasik and Klerk (2006) reported that MeJA reduced the cold requirement (breaking dormancy) for bulblet sprouting in lily species.

In this study, the effects of different sucrose concentrations and the combinations of JA - Auxin (IAA or NAA) and JA - Cytokinin (2iP) on the propagation, rooting and bulb formation was investigated in the hyacinth plant (Hyacinthus orientalis L. subsp. chionophyllus Wendelbo) which is endemic to Turkey.

\section{Materials and Methods}

\section{Plant Material and Surface Sterilization}

The immature capsules of Hyacinthus orientalis subsp. chionophyllus Wendelbo were collected within the Kahramanmaraş province (Turkey) in May. The capsules containing immature embryos were washed in detergent and surface-sterilized for 1 minute in $70 \%$ ethanol and then for 15 minute in $20 \%$ commercial bleach (Axion) adding 1-2 drop Tween-20 with continuous stirring. Then the seeds were rinsed three times with sterile distilled water. The sterilization of the media was done by autoclaving at $121^{\circ} \mathrm{C}$ for $15 \mathrm{~min}$. after adjusting $\mathrm{pH}$ to $5.7+0.1$ Plant material was cultured at $16+0.1^{\circ} \mathrm{C}$ in a 16 -hour photoperiodic climate chamber and sub cultured at 6-week intervals to allow plants to develop.

\section{Culture Conditions}

Capsules were dissected longitudinally with a sterile lancet and the immature embryos were taken out and then transferred to Murashige and Skoog's (MS) media consisted of $2 \mathrm{mg} \mathrm{L}^{-1} \mathrm{BA}+0.5 \mathrm{mg} \mathrm{L}^{-1} \mathrm{IAA}+3.0 \%$ sucrose, $0.7 \%$ agar (Sigma) in petri dishes for germination. The medium $\mathrm{pH}$ was adjusted to 5.6 with $1 \mathrm{~N} \mathrm{NaOH}$ or $1 \mathrm{~N}$ HCI before autoclaving at $121^{\circ} \mathrm{C}$ for 20 minutes. All cultures were kept at $24 \pm 1^{\circ} \mathrm{C}$ under cool-white fluorescent light (35 $\mu \mathrm{mol} \mathrm{m} \mathrm{m}^{-1}$ ) with $16 \mathrm{~h}$ photoperiod. All growth regulators (N6-benzylamino-purine (BAP), 2-isopentenyladenine (2iP), indole-acetic acid (IAA), naphthalene acetic acid (NAA) and jasmonic acid (JA) were filter-sterilized using a Millipore filter $(0.22 \mu \mathrm{m}$ pore size $)$ and added to autoclaved medium before dispensing into petri dishes. The cultures were transferred to fresh media every six weeks. The average number of bulblets, root number, percent roots and size of bulblets recorded after two sub culturing were analysed statistically using factorial completely randomized design. Five bulbs were cultured per treatment and each experiment was repeated three or four times according to the experimental designs.

\section{Sucrose Treatment}

The effect of carbon source in MS (Murashige and Skoog, 1962) media formulation supplemented with $2 \mathrm{mg}$ $\mathrm{L}^{-1} \mathrm{BA}+0.5 \mathrm{mg} \mathrm{L}^{-1} \mathrm{IAA}$ was evaluated by increasing the sucrose concentration $(3.0,4.5,6.0$ and $9.0 \%)$. For the regeneration of bulblets from embryos (approximately 0.5 $1.0 \mathrm{~cm}$ length) were cultured in test tubes. Five test tubes containing one bulb were cultured per treatment and each experiment was repeated three times. The mean number of bulblets per explant and bulblets diameter was evaluated in two subcultures after culture initiation.

\section{JA and Cytokinin Treatment}

Bulblets (approx. 0.5-1.0 cm length) were cultured in MS solidified with $7.5 \mathrm{~g} \mathrm{~L}^{-1}$ agar and containing $3.0 \%$ sucrose and three levels of JA $\left(0.0,1.0\right.$ and $\left.2.0 \mathrm{mg} \mathrm{L}^{-1}\right)$ and 2iP $\left(0.0,0.25\right.$ and $\left.0.50 \mathrm{mg} \mathrm{L}^{-1}\right)$. Bulblets from explants were cultured in vessels contained about $50 \mathrm{ml}$ of medium for regeneration. Magentas containing five explants were cultured per treatment and each experiment was repeated three times. The mean number of bulblets per explant, number of roots and bulblets size was evaluated in two subcultures after culture initiation. 


\section{JA and Auxin Treatment}

The medium with $3.0 \%$ sucrose was supplemented with three concentrations of JA $\left(0.0,1.0\right.$ and $\left.2.0 \mathrm{mg} \mathrm{L}^{-1}\right)$ and IAA or NAA $\left(0.0,0.5\right.$ and $\left.0.1 \mathrm{mg} \mathrm{L}^{-1}\right)$. Developed bulblets (approx. $3.0 \mathrm{~mm}$ in diameter) by $\mathrm{MS}$ medium supplemented with $2.0 \mathrm{mgI}^{-1} \mathrm{BA}+0.5 \mathrm{mg} \mathrm{L}^{-1}$ IAA were determined for these treatments. Bulblets from explants were cultured in vessels containing $50 \mathrm{ml}$ of medium for regeneration. Magentas containing five explants were cultured per treatment and each experiment was repeated three times. The mean number of roots, rooting percentage and bulb diameter were evaluated in two subcultures after culture initiation.

\section{Statistical Methods}

In this study, different sucrose concentration and several combinations of plant growth regulators such as IAA, NAA, 2iP, JA were tested. The data were analysed statistically using factorial completely randomized design consisting of each combination was three replicates consisted of five explants. Data was statistically analysed using the JMP 8.0. Means were separated according to the least significant difference (LSD) test at the 0.05 level of probability. The angle transformation values were calculated from the data in percentage (\%). Variance analysis was done according the literature (Steel and Torrie, 1980; Yurtsever, 1984).

\section{Results and Discussion}

\section{Sucrose Treatment}

After two weeks in culture, most immature hyacinth (Hyacinthus orientalis subsp. chionophyllus Wendelbo) embryos formed shoots in test tubes. Increased sucrose concentrations in the growing media improved the bulblet formations. The rate of explants producing shoots and the number of bulblets per explant was determined after 12 weeks of culture initiation. The largest bulblets with a mean diameter of $7.4 \mathrm{~mm}$ and $7.2 \mathrm{~mm}$ were found on MS medium with BAP $2.0 \mathrm{mg} \mathrm{L}^{-1}+$ IAA $0.5 \mathrm{mg} \mathrm{L}^{-1}$ containing $6.0 \%$ sucrose and $9.0 \%$ sucrose respectively (Table 1 ). The highest number of bulblets (18.2 and 16.9) per explant was on MS medium containing $9.0 \%$ sucrose and $3.0 \%$ sucrose respectively.

In vitro shoot initiation and bulblet regeneration in hyacinth with different sucrose treatments were shown in Figure 1.

Table 1. The effects of different sucrose concentrations in the MS medium (2.0 BAP mg L $\left.\mathrm{m}^{-1}+0.5 \mathrm{IAA}_{\mathrm{mg} \mathrm{L}}^{-1}\right)$ on in vitro bulblet formation in hyacinth.

\begin{tabular}{c|cc}
\hline Sucrose concentration $(\%)$ & Mean bulb diameter $(\mathrm{mm})$ & Mean number of bulblets (number/explant) \\
\hline 3.0 & $5.8^{\mathrm{b}}$ & $16.9^{\mathrm{a}}$ \\
4.5 & $5.2^{\mathrm{b}}$ & $11^{\mathrm{b}}$ \\
6.0 & $7.4^{\mathrm{a}}$ & $14.5^{\mathrm{ab}}$ \\
9.0 & $7.2^{\mathrm{a}}$ & $18.2^{\mathrm{a}}$ \\
\hline
\end{tabular}

Different letters within a column are significantly different (LSD test; $\mathrm{P} \leq 0.05$ )

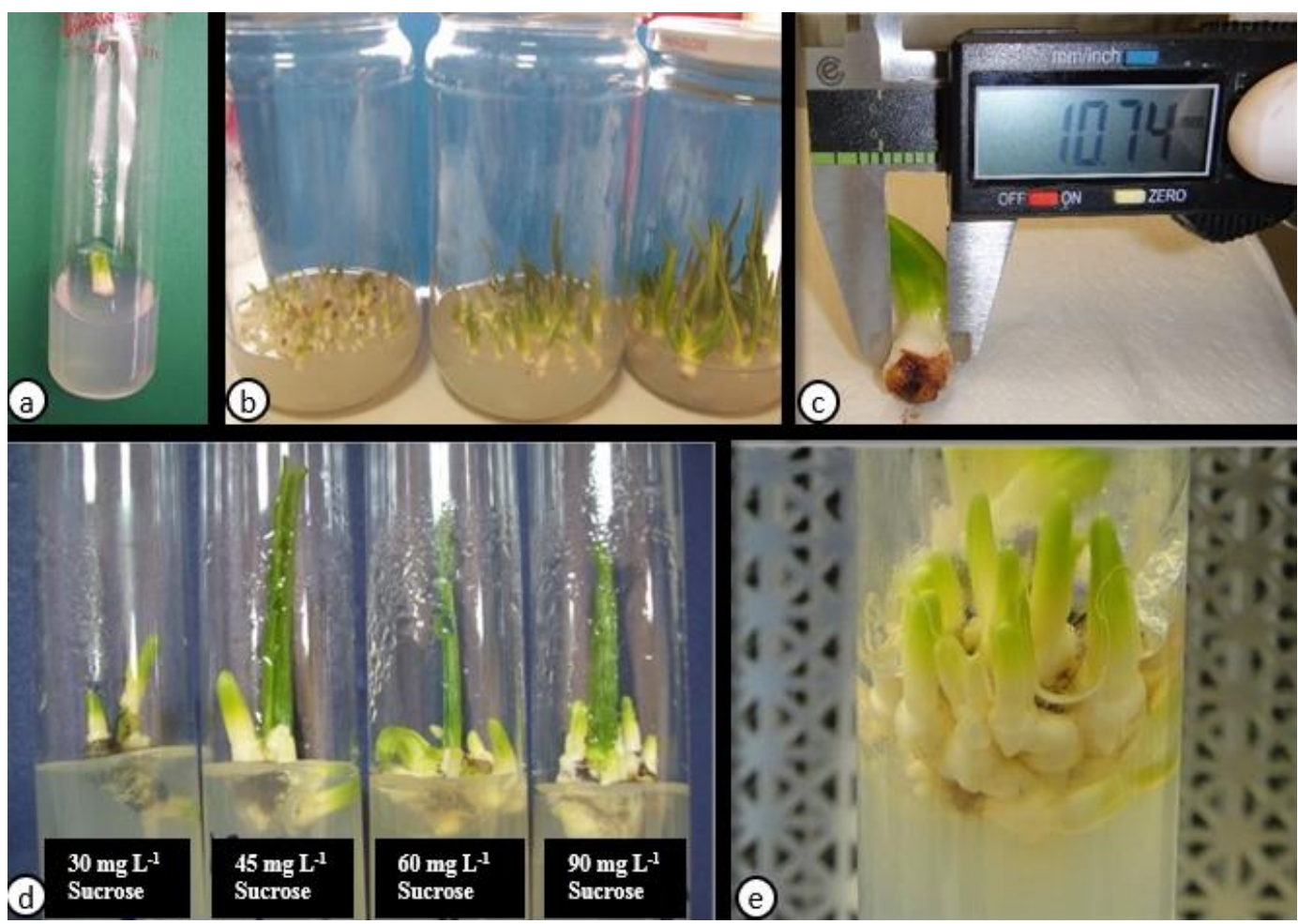

Figure 1. a) Initation of shoots with sucrose in MS medium supplemented with 2.0 BAP mg L $\mathrm{m}^{-1}+0.5 \mathrm{IAA} \mathrm{mg} \mathrm{L}^{-1}$. b) Bulb growth of shoots with 3.0\% sucrose. c) Diameter measurement of a developing bulblet. d) Bulblet formation on the medium containing different sucrose concentration. e) Bulblet formation with $9.0 \%$ sucrose. 
There are many studies indicating the positive effects of increased sucrose concentrations in the growing media on the bulb formations in several plants. Sun et al. (2012) reported that Lilium davidii var. unicolor had $100 \%$ percent success in bulblet formation at the sucrose concentration of $100 \mathrm{~g} \mathrm{~L} \mathrm{~L}^{-1}$, while the diameter of bulblets occurs to the maximum. The increase in sucrose concentration, except standard sucrose concentration (3.0\%), induced a high occurrence of bulblets per explant and a well-developed bulb diameter (approx. 1-36 shoots and 3.46-12.6 mm diameter, respectively). Sucrose at high concentrations promoted in vitro bulbing of shallot (Allium cepa), where a concentration of $50 \mathrm{~g} \mathrm{~L}^{-1}$ sucrose induced $10 \%$ of the plants to form bulbs, whereas bulbing in shallot was not promoted both above and below this concentration (Saos et al., 2002). An increasing sucrose concentration, from 3 to $60 \mathrm{mM}$, stimulated in vitro bulblet formation in Narcissus (Staikidou et al., 1994, 2005). Our study with hyacinth plants also confirmed the positive effect of increased sucrose concentration in the media on in vitro bulb formation.

\section{JA - 2iP Treatment}

In this treatment different concentrations of JA and $2 \mathrm{iP}$ (as a cytokinin source) alone or with their several combinations were used for bulblet formation, shoot and root regeneration from the microbulb explants of hyacinth.
Many newly formed shoots started to grow after 10-12 days of culture in MS medium (3.0\% sucrose) with JA-2iP combinations.

In this experiment, the mean number of bulblets per explant with combinations was often considerably higher than with JA treatments alone (Table 2). The highest number of bulblets (13.7 and 12.4 bulbets per explant) was obtained by using JA $1.0 \mathrm{mg} \mathrm{L}^{-1}+2 \mathrm{iP} 0.25 \mathrm{mg} \mathrm{L}^{-1}$ and $2 \mathrm{iP}$ $0.50 \mathrm{mg} \mathrm{L}^{-1}$, respectively. This was followed with 10.2 bulblets by using JA $2.0 \mathrm{mg} \mathrm{L}^{-1}+2 \mathrm{iP} 0.25 \mathrm{mg} \mathrm{L}^{-1}$ and with 8.4 bulblets by $2 \mathrm{iP} 0.25 \mathrm{mg} \mathrm{L}^{-1}$, which were in the same statistical group.

Number of roots under all applied concentration were higher than in the control group of Hyacinthus orientalis subsp. chionophyllus Wendelbo (Table 2). The addition of only high JA concentration significantly increased the mean number of roots per explant. Similarly, Silva Maia and Pedroso-de-Moraes, (2017) reported a positive increase in the number of roots when the addition of JA to the culture medium showed the best result for rooting TDZ was used with NAA. The highest number of roots (19.9 per explant) was obtained by using 2.0 JA alone. Also the other combinations had a higher number of roots (ranged from 10.3 to 15.7 ) per explant than that of the control treatment which had only 6.3 roots. But these differences were not statistically significant $(\mathrm{P} \leq 0.05)$.

Table 2. Effects of JA, 2iP and their combinations in the MS medium (containing 3\% sucrose) on the number of bulblets and roots, and bulb diameter of the hyacinth plants.

\begin{tabular}{l|ccc}
\hline $\begin{array}{c}\text { Plant growth regulator concentrations } \\
\text { and combinations (mg L }\end{array}$ & $\begin{array}{c}\text { Mean number of bulblets } \\
\text { (number/explant) }\end{array}$ & $\begin{array}{c}\text { Mean number of roots } \\
\text { (number/explant) }\end{array}$ & $\begin{array}{c}\text { Mean bulb diameter } \\
(\mathrm{mm})\end{array}$ \\
\hline JA 1.0 & $5.1^{\mathrm{b}}$ & $11.6^{\mathrm{bc}}$ & $7.0^{\mathrm{ab}}$ \\
JA 2.0 & $5.2^{\mathrm{b}}$ & $19.9^{\mathrm{a}}$ & $7.9^{\mathrm{a}}$ \\
2iP 0.25 & $8.4^{\mathrm{ab}}$ & $14.5^{\mathrm{ab}}$ & $6.9^{\mathrm{ab}}$ \\
2iP 0.50 & $12.4^{\mathrm{a}}$ & $10.3^{\mathrm{bc}}$ & $6.4^{\mathrm{bc}}$ \\
JA 1.0+2iP 0.25 & $13.7^{\mathrm{a}}$ & $15.7^{\mathrm{ab}}$ & $5.7^{\mathrm{bcd}}$ \\
JA 1.0 +2iP 0.50 & $6.8^{\mathrm{b}}$ & $12.5^{\mathrm{abc}}$ & $5.2^{\mathrm{cd}}$ \\
JA 2.0 +2iP 0.25 & $10.2^{\mathrm{ab}}$ & $13.0^{\mathrm{abc}}$ & $6.3^{\mathrm{bc}}$ \\
JA 2.0 +2iP 0.50 & $6.6^{\mathrm{b}}$ & $13.3^{\mathrm{abc}}$ & $6.4^{\mathrm{bc}}$ \\
\hline Control & $6.5^{\mathrm{b}}$ & $6.3^{\mathrm{c}}$ & $4.4^{\mathrm{d}}$ \\
\hline
\end{tabular}

Different letters within a column are significantly different (LSD test; $\mathrm{P} \leq 0.05$ )

Table 3. Effect of Auxins and JA and their combination of the root number, percentage of the roots and the bulb diameter of in vitro grown hyacinth plants.

\begin{tabular}{|c|c|c|c|}
\hline $\begin{array}{l}\text { Plant growth regulator concentration } \\
\text { and combinations }\left(\mathrm{mg} \mathrm{L}^{-1}\right)\end{array}$ & $\begin{array}{l}\text { Mean number of roots } \\
\text { (number/explant) }\end{array}$ & $\begin{array}{c}\text { Rooting } \\
\text { percentage }(\%)\end{array}$ & $\begin{array}{l}\text { Mean bulb diameter } \\
(\mathrm{mm})\end{array}$ \\
\hline IAA 0.5 & $1.0^{\mathrm{b}}$ & $(46.92)^{* a b c}$ & $6.92^{\mathrm{abc}}$ \\
\hline IAA 1.0 & $1.5^{\mathrm{b}}$ & $(46.92)^{\mathrm{abc}}$ & $7.62^{\mathrm{ab}}$ \\
\hline IAA $0.5+$ JA 1.0 & $13.1^{\mathrm{a}}$ & $(72.29)^{\mathrm{ab}}$ & $8.5^{\mathrm{a}}$ \\
\hline IAA $0.5+$ JA 2.0 & $3.2^{\mathrm{b}}$ & $(76.92)^{\mathrm{a}}$ & $6.9^{\mathrm{abc}}$ \\
\hline IAA $1.0+$ JA 1.0 & $2.7^{\mathrm{b}}$ & $(63.84)^{\mathrm{ab}}$ & $5.1^{\text {bcd }}$ \\
\hline IAA $1.0+$ JA 2.0 & $17.9^{\mathrm{a}}$ & $(81.14)^{\mathrm{a}}$ & $9.1^{\mathrm{a}}$ \\
\hline NAA 0.5 & $3.8^{\mathrm{b}}$ & $(76.92)^{\mathrm{a}}$ & $5.8^{\mathrm{abcd}}$ \\
\hline NAA 1.0 & $1.6^{\mathrm{b}}$ & $(47.71)^{\mathrm{abc}}$ & $5.8^{\mathrm{abcd}}$ \\
\hline NAA $0.5+$ JA 1.0 & $4.1^{\mathrm{b}}$ & $(72.29)^{\mathrm{ab}}$ & $5.9^{\mathrm{abcd}}$ \\
\hline NAA $0.5+$ JA 2.0 & $0.9^{\mathrm{b}}$ & $(42.29)^{\mathrm{abc}}$ & $4.3^{\mathrm{cd}}$ \\
\hline NAA $1.0+$ JA 1.0 & $0.4^{\mathrm{b}}$ & $(21.93)^{\mathrm{c}}$ & $3.6^{\mathrm{d}}$ \\
\hline NAA $1.0+$ JA 2.0 & $0.2^{\mathrm{b}}$ & $(30.78)^{b c}$ & $4.2^{\text {cd }}$ \\
\hline Control & $4.4^{\mathrm{b}}$ & $(64.22)^{\mathrm{ab}}$ & $5.6^{\mathrm{abcd}}$ \\
\hline
\end{tabular}

*Values in parentheses indicate arcsine transformed \% values. 


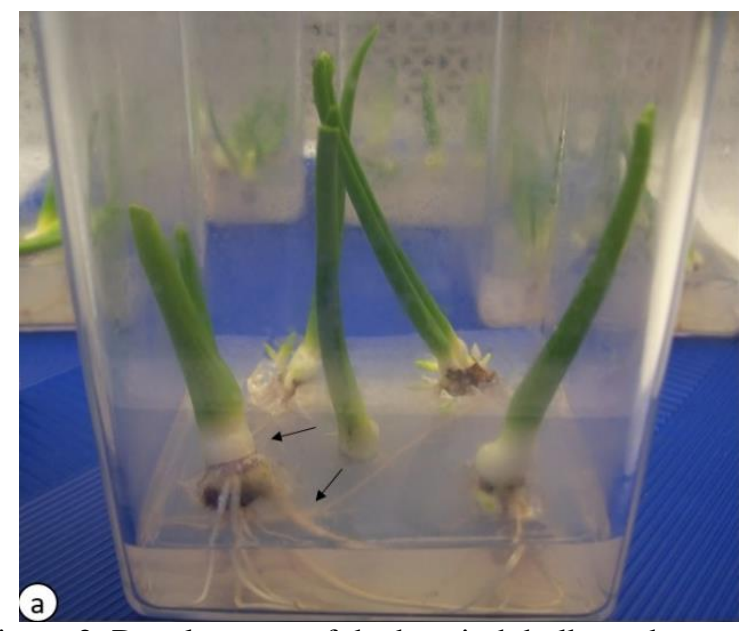

Figure 2. Development of the hyacinth bulbs and roots on MS medium supplemented with JA $2.0 \mathrm{mg} \mathrm{L}^{-1}$.
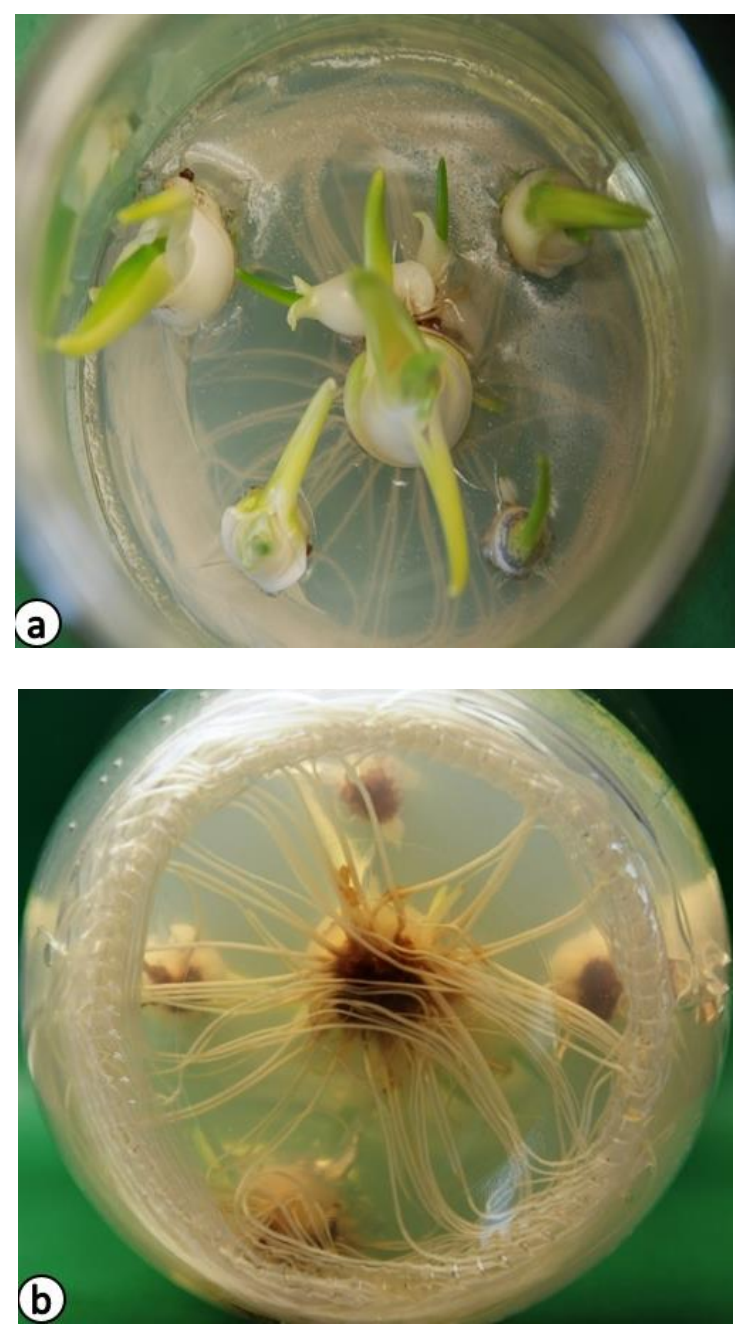

Figure 3. a-b) Root formation and bulb growth of in vitro hyciant plants promoted by the combination of IAA 1.0 $\mathrm{mg} \mathrm{L} \mathrm{L}^{-1}+\mathrm{JA} 2.0 \mathrm{mg} \mathrm{L}^{-1}$.

The largest bulblets with the mean diameter of $7.9 \mathrm{~mm}$ were found on MS medium supplemented with JA $2.0 \mathrm{mg}$ $\mathrm{L}^{-1}$. This was closely followed by using JA $1.0 \mathrm{mg} \mathrm{L}^{-1}$ with $7.0 \mathrm{~mm}$ and $2 \mathrm{iP} 0.25 \mathrm{mg} \mathrm{L}^{-1}$ with $6.9 \mathrm{~mm}$, which were in the same statistical group. The bulb diameter was smallest with $4.4 \mathrm{~mm}$ on the MS medium without plant growth regulators (Control).
As seen in Figure 2, the best bulb and root development of the hyacinth plant was obtained on MS medium supplemented with JA $2.0 \mathrm{mg} \mathrm{L}^{-1}$.

\section{$J A-$ Auxin treatment}

The results of root formation from plantlets obtained on MS media containing various concentrations of IAA and NAA and with or without JA after 12 weeks in culture were given in Table 3.

The mean root number per bulblet was highest (17.9 number/explant) in MS medium supplemented with IAA $1.0 \mathrm{mg} \mathrm{L}^{-1}+\mathrm{JA} 2.0 \mathrm{mg} \mathrm{L}^{-1}$ combination, followed by IAA $0.5 \mathrm{mg} \mathrm{L}^{-1}+\mathrm{JA} 1.0 \mathrm{mg} \mathrm{L}^{-1}$, combinations with 13.1 roots (Table 3 ). The root number of certain combinations was as low as 0.4 (NAA $1.0 \mathrm{mg} \mathrm{L}^{-1}$, NAA $1.0 \mathrm{mg} \mathrm{L}^{-1}+\mathrm{JA} 1.0 \mathrm{mg}$ $\mathrm{L}^{-1}$ or NAA $1.0 \mathrm{mg} \mathrm{L}^{-1}+\mathrm{JA}_{2} .0 \mathrm{mg} \mathrm{L}^{-1}$ ). The root formation rate was highest in IAA $1.0 \mathrm{mg} \mathrm{L}^{-1}+\mathrm{JA} 2.0 \mathrm{mg} \mathrm{L}^{-1}$ with $81.14 \%$. This was closely followed by IAA $0.5 \mathrm{mg} \mathrm{L}^{-1}+$ JA $2.0 \mathrm{mg} \mathrm{L}^{-1}$ and IAA $0.5 \mathrm{mg} \mathrm{L}^{-1}+\mathrm{JA} 2.0 \mathrm{mg} \mathrm{L}^{-1}$ combinations with the same percentage $(76.92 \%)$, being in the same statistical group (Table 3).

The bulb diameters were the largest of the MS medium

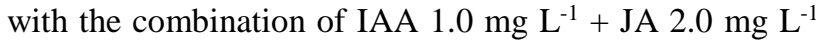
with $9.1 \mathrm{~mm}$ or by IAA $0.5 \mathrm{mg} \mathrm{L}^{-1}+\mathrm{JA} 1.0 \mathrm{mg} \mathrm{L}^{-1}$ with $8.5 \mathrm{~mm}$. The bulb and root development of the plants in MS medium with several combinations of NAA-JA did not differ significantly compared to that of the control plants. The lowest bulb diameter with $3.6 \mathrm{~mm}$ was recorded on MS medium supplemented with NAA $1.0 \mathrm{mg} \mathrm{L}^{-1}$ and JA $1.0 \mathrm{mg} \mathrm{L}^{-1}$. It was also observed that the root development was directly proportional to the bulb diameter. In this experiment the best root regenaration and bulb development were obtained with the combination of IAA $1.0 \mathrm{mg} \mathrm{L}^{-1}+\mathrm{JA}^{2} .0 \mathrm{mg} \mathrm{L}^{-1}$ (Figure 3).

The results revealed that bulb formation was better with the application of IAA-JA combination than with the combination of NAA-JA. Saniewski (1974) reported that the best concentration for the induction of bulb formation in Hyacinthus orientalis was the medium containing 10 ppm $\mathrm{BA}+1$ ppm NAA, and indicated that the concentration of NAA was necessary for root differentiation and callus formation. On the contrast, in our study NAA-JA combination did not effectively promote root production. Xiao Mei (2010) reported that the best concentration for the induction of root formation in Hyacinthus orientalis was MS medium supplemented with $1 / 2 \mathrm{MS}+0.2 \mathrm{mg} \mathrm{L}^{-1} \mathrm{NAA}$. However, in this present study another form of auxin (IAA) supplemented with JA was more effective in promoting the rooting percentage of in vitro plantlets of endemic Hyacinthus orientalis subsp. chionophyllus Wendelbo grown in Turkey.

\section{Conclusion}

Turkey has a rich endemic plant pool, however, most of the endemic plants are at on the risk of extinction (Ekim et al., 2000). Unfortunately, a comprehensive conservation program, including the proper propagation methods of certain endemic plants have not been established yet (Bulut and Yilmaz, 2010). Therefore more studies are needed to develop suitable in vitro propagation protocols. Since the interaction of the plant growth regulators in the process of in vitro propagation of the ornamental geophyte plants 
might differ according to the species or even with the explant types used. Efficient bulblet regeneration has been obtained from immature embryo explants of different geophytes such as Stenbergia fischeriana (Mirici et al., 2005), Tulipa karamanica and Tulipa sintenesii (Kalyoncu et al., 2006), Muscari mirum (Nasircilar et al., 2009), Hyacinthus orientalis (Kizil et al., 2016), Iris kirkwoodii (Doğan and Çağlar, 2018). The most important factors affecting in vitro plant regeneration are plant growth regulators, plant genotype, plant age, plant collect time, habitat and explants type (Nasircilar et al., 2009; Özcan, 2002, Doğan and Çağlar, 2020). In this study, the addition of JA or in combination with IAA or $2 \mathrm{iP}$ in the growing media containing sucrose improved the micropropagation success and bulb formation of the hyacinth explants. Moreover, this protocol, in which immature embryos are used as explant source can be applied for rapid propagation of other geophytes species with potential for ornamental The methods and findings of the present study might also be used in further studies for obtaining a better proliferation rate and improving the bulb development in other Hyacinth species as well as in other geophyte species.

\section{References}

Altundağ E, Öztürk M. 2011. Ethnomedicinal Studies on the Plant Resources of East Anatolia (Turkey), Procedia Soc. Behav Sci. 19(2011) 756-777

Bach A. 1992. Micropropagation of Hyacinths (Hyacinthus orientalis L.). In: Bajaj YPS (ed) Biotechnology in Agriculture and Forestry, vol 20: High-tech and Micropropagation, vol 4. Springer, Berlin Heidelberg New York, pp 144-159

Bulut Z, Y1lmaz H. 2010. The Current Situation of Threatened Endemic Flora in Turkey: Kemaliye (Erzincan) Case. Pak. J. Bot. 42(2): 711-719

Çetin B, Eren H, Oskay D, Akanıl N. 2016. Bingöl Kritik Tehlikedeki (CR) Endemik Erodium somanum Türünün In vitro Mikroçoğaltımı. CBÜ Fen Bil. Dergi., Cilt 12, Sayı 1, $115-120 \mathrm{~s}$

Çömlekçioğlu N, Karaman Ş. 2008. Kahramanmaraş Şehir Merkezindeki Aktarlarda Bulunan Tibbi Bitkiler, KSÜ Mühendislik Derg. 11(1)23-32

Çördük N, Yücel G, Akıncı N, Tuna M, Esen O. 2017. In vitro Propagation of Silene bolanthoides Quézel, Contandr. \& Pamukç. and Assessment of Genetic Stability by Flow Cytometry. Arch Biol Sci. 2018;70(1):141-148

Doğan S, Çağlar G. 2018. In vitro shoot proliferation via immature embryos of Iris kirkwoodiae Chaudhary. Anadolu, J. of AARI 28 (2): 48-54.

Doğan S, Çağlar G. 2020. Iris sari SCHOTT ex BAKER'in In vitro Çoğaltım ve Köklendirme Çalışmaları. ANADOLU, J. of AARI, 2020, 30 (1): 33-45

Ekim T, Koyuncu M, Vural M, Duman H, Aytaç Z, Adıgüzel N. 2000. Red Data Book of Turkish Plants (Pteridophyta and Spermatophyta). Turkish Association for the Conservation of Nature \& Van Centennial University, ISBN: 975-93611-0-8, Barışcan Ofset, 246pp, Ankara

Halmer P, Bewley JD. 1982. Control by External and Internal Factors Over the Mobilization of Reserve Carbohydrates in Higher Plants. In:Loewus, F.A.L., Tanner, W.(ed.) Encyclopedia of Plant Physiology. New Series Vol. 13A. Pp.748-793. Springer-Verlag, Berlin-Heidelberg-New York 1982

Heidema FT, Grevers G, Gorin N, Van de Hulst CThC, Franssen JM. 1985. Criteria Related to Precooling of Tulips Bulbs cv. apeldoorn at $5^{\circ} \mathrm{C}$. Acta Hort. 177: $341-346$
Jásık J, De Klerk GJ. 2006. Effect of Methyl Jasmonate on Morphology and Dormancy Development in Lily Bulblets Generated In vitro. Journal of Plant Growth Regulation. 25: $45-51$

Jansky S, Hamernik A. 2015. Rapid Cycling of Potato Tuber Generations by Overcoming Dormancy. Am. J. Potato Res. 2015, 92, 148-152

Kahraman S, Kocabas YZ, 2001. Traditional Medicinal Plants of K.maraş(Turkey), Science, 1(3)125-128

Kalyoncu DD, İpek A, Parmaksız İ, Arslan N, Sancak C, Özcan S. 2006. In vitro Bulblet Production in Wild Tulipa species. Agricultural Constraints in the Soil-Plant Atmosphere Continum Proceedings of the International Symposium, pp.289-292.Ghent, Belgium

Kayıran SD, Özkan EE. 2017. The Ethnobotanical Uses of Hyacinthaceae Species Growing in Turkey and Review of Pharmacological Activities. Indian Journal of Traditional Knowledge, Vol. 16(2), April 2017, pp.243-250

Khodorova NV, Boitel-Conti M. 2013. The Role of Temperature in the Growth and Flowering of Geophytes. Plants 2013, 2, 699-711; doi:10.3390/plants2040699

Kizil S, Sesiz U, Khawar KM. 2016. Improved In vitro Propagation of Hyacinthus orientalis L. Using Fruits Containing Immature Zygotic Embryos and Tender Leaf Sheath as Explants. Acta Sci. Pol. Hortorum Cultur, 15(5) 2016, 15-30

Koda Y. 1997. Possible Involvement of Jasmonates in Various Morphogenic Events. Physiol Plant 100: 639-946

Lian ML, Chakrabarty D, Paek KY. 2003. Bulblet Formation from Bulbscale Segments of Lilium Using Bioreactor System. Biol. Plant. 46:199-203

Li-Nagasuga K, Okubo H, Ozaki Y, Nakano T. 2000. Differential Display of Genes Induced by Low Temperature in Bulb Formation of Hyacinth, ISHS Acta Horticulturae 570:VIII International Symposium on Flowerbulbs. 10.17660/ActaHortic.2002.570.46

Mirici S, Parmaksız I, Ozcan S, Sancak C, Uranbey S, Sarıhan EO, Gumuscu A, Gurbuz B, Arslan N. 2005. Efficient Ín vitro Bulblet Regeneration from Immature Embryos of Endangered Sternbergia fischeriana. Plant Cell, Tissue and Organ Culture(2005) 80: 239-246

Murashige T, Skoog F. 1962. A Revised Medium for Rapid Growth and Bioassay with Tobacco Tissue Cultures. Physiol. Plant, 15: 473-497

Nasircilar AG, Mirici S, Karagüzel Ö, Eren Ö, Baktir İ. 2009. In vitro Propagation of Endemic and Endangered Muscari mirum from Different Explant Types. Turk J Bot 35: (2011) $37-43$

Nojiri H, Yamane H, Seto H, Yamaguchi I, Murofushi N, Yoshihara T, Shibaoka H. 1992. Qualitative and Quantitative Analysis of Endogenous Jasmonic Acid in Bulbing and NonBulbing Onion Plants. Plant Cell Physiol 33: 1225-123

Oluk AE, Çakır A (2009). Micropropagation of Origanum sipyleum L., an Endemic Medicinal Herb of Turkey. African Journal of Biotechnology Vol. 8 (21), pp. 5769-5772

Özcan S. 2002. Effect of Different Genotypes and Auxins on Efficient Somatic Embryogenesis from Immature Zygotic Embryo Explants of Maize. Biotechnol- Biotechnological Equipment 16: 51-57

Pierik RLM, Steegmans HHM. 1975. Effect of Auxins, Cytokinins, Gibberellins, Abscisic Acid and Ethephon on Regeneration and Growth of Bulblets on Excised Bulb Scale Segments of Hyacinth, Physiologia Plantarum. Volume 34, Issue 1, pp.14-17

Podwyszynska M. 2004. Improvement of Bulb Formation in Micropropagated Tulips by Treatment with Naa and Paclobutrazol or Ancymidol, ISHS Acta Horticulturae 725: V International Symposium on in vitro Culture and Horticultural Breeding 
Podwyszynska M, Kosson R, Treder J. 2015. Polyamines and Methyl Jasmonate in Bulb Formation of In vitro Propagated Tulips. Plant Cell Tiss Organ Cult (2015) 123:591-605

Ravnikar M, Rode J, Gogala N, Benedicic D. 1990. Regulation of Organogenesis with Jasmonic Acid. Acta Horticulturae, 280, $169-172$

Ravnikar M, Zel J, Plaper I, Spacapan A. 1993. Jasmonic Acid Stimulates Shoot and Bulb Formation of Garlic In vitro. J Plant Growth Regul 12: 73-77

Saniewski M, Nowak J, Rudnicki R. 1974. Studies on the Physiology of Hyacinth Bulbs (Hyacithus orientalis L.) 1V. Hormonal Regulation of Induction on Roots and Bulblets in Hyacinthus orientalis L. Grown in Culture. Plant Sci. Let.Vol. 2, Issue 6, pp. 373-376

Santos I, Salema R. 2000. Promotion by Jasmonic Acid of Bulb Formation in Shoot Cultures of Narcissus triandrus L. Plant Growth Regulation 30: 133-138, 2000

Saos FG, Hourmant A, Esnault F, Chauvin E. 2002. In vitro Bulb Development in Shallot (Allium cepa L. Aggregatum group): Effects of Anti-gibberellins, Sucrose and Light. Ann Bot. 89: $419-425$

Sevindik B, İzgü T, Şimşek Ö, Tütüncü M, Çürük P, Yılmaz Ö, Kaynak G, Kaçar AY, Teixeira da Silva J A, Mendi YY. 2018. In vitro Culture of Turkish Origanum sipyleum L. American Journal of Plant Biology 2017; 2(5-1): 32-36

Shibli RA, Ajlouni MM. 2000. Somatic Embryogenesis in the Endemic Black Iris. Plant Cell. Tissue and Organ Culture $61: 15-21$

Silva Maia JA, Pedroso-de-Moraes C. 2017. Influence of Different Concentrations of Jasmonic Acid on In vitro Development of Catasetum fimbriatum Lindl. (Orchidaceae). Modern Phytomorphology 11: 99-104

Squires WM, Langton FA, Fenlon JS. 1991. Factors Influencing the Transplantation Success of Micropropagated Narcissus Bulbils. J Hortic Sci. 66: 661-671

Staikidou I, Selby C, Harvey BMR. 1994. Stimulation by Auxin and Sucrose of Bulblet Formation In vitro by Single Leaf Cultures of Narcissus. New Phytol. 127: 315-320

Staikidou I, Sally W, Harvey BMR, Selby C. 2005. Narcissus Bulblet Formation In vitro: Effects of Carbohydrate Type and Osmolarity of the Culture Medium. Plant Cell Tiss. Organ Cult. 80: 313-320
Steel RGD, Torrie JH. 1980. Principles and Pocedures of Statistics. Second Ed. McGraw-Hill Book Company Inc., New York

Sun M, Shi JF, Zhang QX. 2012. Effects of Sucrose Concentration on the Bulblet Formation and Growth of Three Lilies In vitro (Edited by: Wang, D). Materials for Environmental Protection and Energy Application, 343-344, 1276-1280

Sun X, Li Y, Yang H, Cui W, Wang Y. 2010. Rapid Micropropagation System via In vitro Culture in Hyacinthus orientalis L. Journal of Shenyang Agricultural University, 2010-01

Taeb AG, Alderson PG. 1990. Effect of Low Temperature and Sucrose on Bulb Development and on the Carbohydrate Status of Bulbing Shoots of Tulip In vitro. J Hortic Sci:193197

Takayama S, Misawa M. 1980. Differentiation in Lilium Bulbs Cales Grown In vitro. Effect of Activated Charcoal, Physiological Age Of Bulbs And Sucrose Concentration on Differentiation and Scale Leaf Formation In vitro. Physiol. Plant. 48:121-125

Tuzlacı E, Doğan A. 2010. Turkish Folk Medicinal Plants, XI: Ovacik(Tunceli) Marmara Pharmaceutical Journal 14:136143

Uranbey S. 2010. In vitro Bulblet Regeneration from Immature Embryos of Muscari azureum. African Journal of Biotechnology Vol. 9(32), pp. 5121-5125

Xiao Mei S, Yan L, Hong Guang Y, Wen Shan C, Ya Bin W. 2010. Rapid Micropropagation System via In vitro Culture in Hyacinthus orientalis L. Journal of Shenyang Agricultural University. Vol. 41 No. 1 pp. 33-36

Yurtsever N. 1984. Deneysel Istatistik Metotları. Köy Hizmetleri Toprak ve Gübre Arş. Enst. Müdürlüğü Yavınları Genel Yayın No. 121 Ankara

Yüzbaşığlu D. 2003. Türkiye Endemiği Hycinthus orientalis subsp. chionophilus Wendelbo (Liliaceae) Alttüründe Karyolojik Bir Çalışma. Sistematik Botanik Dergisi 10,2, 151-162,2003-ISSN 130-2953

Zimmerman DC, Vick BA. 1983. Stimulation of Adventitious Rooting in Mung Bean Seedlings by Jasmonic Acid and 12Oxo-Phytodi- Enoic Acid. Plant Physiol. 72(suppl): 108 